\title{
The Implications of Metaphysical "Doubt" in Shakespeare's Hamlet
}

\author{
Lotfi Salhi (Corresponding author) \\ University of Gafsa, Tunisia \\ Email: lotfisalhi1123@gmail.com
}

Received: $13 / 04 / 2021$

Accepted: 05/07/2021

Published: 01/09/2021

Volume: 2 Issue: 5

How to cite this paper: Salhi, L. (2021). The Implications of Metaphysical "Doubt" in

Shakespeare's Hamlet. Journal of Critical Studies in Language and Literature, 2(5), 6-10

DOI: https://doi.org/10.46809/jcsll.v2i5.79

DOR: https://dorl.net/dor/20.1001.1.27324605.2021.2.5.2.0

Copyright (C) by author(s) and Global Talent Academy Ltd. This work is licensed under the Creative Commons Attribution International License (CC BY 4.0).

http://creativecommons.org/licenses/by/4.0/

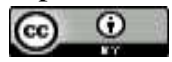

\begin{abstract}
In his likening of Shakespeare's Hamlet to a sponge which absorbs all the problems of our time ${ }^{1}$, the Polish poet, critic, and Professor of Literature Jan Cott implies that Hamlet will continue to be contemporary no matter what time has passed. The timelessness of the play derives in the first place from its liability to re-interpretation and re-contextualization in different political and social circles by virtue of its humanitarian, existential and metaphysical implications. The skeptical philosophy background of "Knowledge and suspicion" seems to have had its profound impact on Shakespeare that he can be seen more like an ideological thinker and philosopher than simply a playwright. In Hamlet the Bard problematizes the philosophical nature of the human individual and puts into question the individual's relation to matters of decision-making, fate and willpower. The play puts into true moral test the nature of the human soul as a plot which moves the action forward, and simultaneously reflects on questions of relevance to knowledge and doubt. This article seeks to explore points of intersection between Hamlet and the philosophy of doubt, which lingered over the Renaissance and throughout the seventeenth century. The Central questions evoked revolve around two postulations: whether certainty about knowledge is reachable, and whether Prince Hamlet and ourselves are the ones who choose our destinies or whether our fates are pre-determined and we cannot change anything but yield in full subservience.
\end{abstract}

Keywords: Doubt, Hamlet, Action, Knowledge, Destiny

\section{Introduction}

First staged in South East Asia (present day Indonesia) in 1609, Shakespeare's play Hamlet tells the story of prince Hamlet of Denmark whose primary concern to avenge his father's death turns into melancholic and speculative contemplations. Hamlet hears news from the ghost of his dead father, who declares he is his father's spirit and tells him that his uncle Claudius killed his father, usurped his throne and married his wife Gertrude- Hamlet's mother. The ghost urges Hamlet to take revenge. Hamlet devotes himself to revenge but delays action on the basis of lack of evidence and absence of sufficient knowledge. The rest of the play depicts Hamlet's relationship with Ophelia; he loves her, but begins to treat her cruelly for no clear reasons. Hamlet mistakenly kills Ophelia's father and she suicides afterwards. Then, in the final scene, Hamlet kills his uncle Claudius, and his mother unknowingly drinks a poisoned wine that was intended for the former to drink. Hamlet dies from wounds as a result of his duel with Ophelia's brother, and thus ends this tragedy of revenge. The focal argument in the play is about Hamlet who spends onto procrastination too much energy that should normally have into creative revenge action. 


\section{Doubt in Hamlet: A Philosophy and a Dramatic Strategy}

\subsection{The Philosophical Connotations of Hamlet's Doubt}

One distinguishing feature of Shakespeare's play is the playwright's choice to portray a hero who cannot find his whererabouts. Prince Hamlet is skeptical, philosophical and totally at odds with the world around him. He rather seems to have lost direction that he can neither distinguish between fact and fiction nor make up his mind. Although Hamlet has heard from Horatio and watched his father's ghost himself and felt his urgences to take revenge for his dead father, he is still thoughtful and hesitant about performative action. Shakespeare puts his protagonist in very critical and exciting circumstances that people rarely encounter. He is at the same time committed to take revenge and prevented from real action due to doubt and uncertainty. Such a situation reverses roles: instead of being armed with determination and resolution, Hamlet is haunted by doubt and characterized by indecision and and incapacity to make up his mind. He is rather so contemplative and skeptical about everything that he spends onto procrastination too much energy that should normally have gone into manipulative action. And though doubt hinders action and renders it far-reaching, it is also symbolic in the sense that it provokes questions of relevance to the nature of human knowledge and to the meaning of existence.

As an epistemological concern, the notion of doubt raises an important interrogation about the possibility that Hamlet may reach a certain knowledge which may allow him to make up his mind and turn into reality the act of revenge. In fact, the crossover between Hamlet and epistemological skepticism lures us to look for the influences underlying Shakespeare's represenatation of his hero. Here Shakespeare not just plays the role of the playwright but also puts on the shoes of the philosopher by highlighting an important metaphysical phenomenon: knowledge and doubt. Using Hamlet's erratic behaviour as a starting point to his philosophical position, Shakespeare raises the questions about whether it is possible for his hero, and for humanity at large, to establish a certain knowledge about the world and about himself/itself. In so doing, Shakespeare capitalizes on the notion of doubt as a philosophical phenomenon to highlight the presumption that our image of the world, things and people is the product of our perception and reception of it, which may not really reflect the reality of the world as it is.

Prince Hamlet is doubtful and contemplative of the ghost's parole probably because he imagines it not to be real. Skepticism, or identity error, therefore, inhibits him from knowledge that may lead to his self-assurance. It is worth noting here that this tendency toward doubt which characterizes Shakespeare's hero is Shakespeare's heritage from Greek philosophy, particularly from Socrates whose conversations with the Athenians about the meaning of concepts like beautiful, ugly, good and malicious culminated in his famous declaration that "all he knew was that he knew nothing" (6). By the same token, Hamlet says to Rosencrantz: "There is no bad thing or good thing. Thinking is what makes things so." (Act 2, scene 2) which brings us back to the Aristotelian notion of doubt- the idea that things appear to us in one way or another not because they are so but because of the suspicion, illusion and belief we put on them that finally make them appear as such. Similarly, in his Apology for Actors (1612) the English playwright and actor Thomas Heywood puts it another way when he talks about the fascinating interaction between stage and audience that gives the audience freedom to endow events with meaning or to make them devoid of emotional and cognitive influence on the audience.

The notion of uncertainty, or doubt, threfeore, places Hamlet at the crossroads of various contradictions. Shakespeare makes us believe that Hamlet's main inclination is to think, not act. This makes him find in the most insignificant and simple arguments to contemplate and to distract himself from his main goal. Prince Hamlet is anxious for action and haunted by a counter urgent desire to escape from action achievement, which makes all his energy on determination evaporate as a result of inaction rebukes. Hamlet bears multifarious contradictions: he is provoked and at the same time banned from both understanding and reaction. Shakespeare is perhaps intentional and purposeful when he places Hamlet in such a state of inconsistency. In his book Shakespearean Criticism Samuel Taylor Coleridge writes: "Shakespeare never wrote Hamlet without careful prior planning"(18). In another part of the book he puts it differently when he says: "I believe that he used to think about the story before writing it, just as the painter thought about his subject and his tools before he painted" (95). Coloridge's view is that Shakespeare's intention behind his depiction of Hamlet's behaviour is to portray the individual's relation with the outside world and to show that he has no desire or interest in identifying with it. The outside world is purely dark and obscure. This lack of desire results in man's- as is embodied in Hamlet's- tendency to doubt his relation with the exterior world and to think deeply about why things happen as they do in the same manner prince Hamlet does in Hamlet.

Shakespeare's point is perhaps that action is a very determining factor of human existence. The superior capacities of the mind are worthless when they cause us to give up our hatred for certain inaction and opt for thought instead. Hamlet was cognitively inclined to deep thought about action until the time has passed and the moment when he could have done something "effective" is past. And because Hamlet did not transform thought into action, he was occupied with thinking about his impotence instead. His thought about his impotence and idleness provided him with another opportunity for laziness. Hence, Hamlet's procrastination does not emanate from his distaste of the crime but from his desire to indulge his imagination in embodying its gravity and heinousness. The actual object of implementation for Hamlet is, therefore, to think, not to act. He finds in his most insignificant arguments an excuse to think about them again, and to distract himself from his main goal.

Drawing on Coleridge, Shakespeare puts Hamlet in very special circumstances that individuals scarcely face. Hamlet is the presumed heir to the throne. His father had died in mysterious conditions, and his mother removed him from the throne after she married his uncle. The effect of this on Hamlet is extremely painful. He is not only living with the urgence he feels 
to take revenge and carry out the duty he is entrusted with, but also has to bear the nightmare of endless questions that constantly keeps haunting him. Hamlet has to reconcile between opposites: he loves to live with determination and anxiety of his mind for action on the one hand, and is at the same time also haunted by the counter-desire which inhibits him from action on the other hand. All this contributes to the creation of the ambiguous and puzzling character of Hamlet. Yet, what makes Hamlet so doubtful and hesitating is a question which bears various interpretations.

\subsection{Doubt as a Dramatic Strategy}

Ambiguity and doubt function like Shakespeare's dramatic strategy to conceal Hamlet's plans and to prevent him from exposing himself openly to the audience. In The Moral Vision of Jacobean Tragedy Robert Ornstein sheds much light on the role of the doubtful and the imaginary in sustaining Hamlet's "strange temper" and protecting him from self revelation. It is through the use of allegories, vague, indirect and unclear language that Hamlet managed to conceal his real intentions from the other actors, particularly from his uncle Claudius. What ensues is that these actors are beguiled into deepening their belief that Hamlet is crazy, but the audience can access the reality of the situation. Through that mask of "weird mood" ${ }^{2}$ Hamlet conveys many messages that startle even a wise audience. Thus, Hamlet's imagination plays a "new" role in the dramatic structure and plot development of the play that is similar in its function to the role imagination also plays in king Lear. Throughout the play Hamlet sounds more like a man of reflection and contemplation than a man action, and through his presmued inclination to the imaginary he succeeded in enclosing his audience in a mysterious and puzzling world.

The mystery of Hamlet's world is an important part of the play that Shakespeare intentionally wants to share with his audience starting from its first mysterious scene in the middle of that cold night at Elsinore to Hamlet's melancholy and pensive behaviour in the remaining scenes. Hamlet's mystery is not a mystery of will and reason, nor is it one of a philosophical mind or temperamental nature incapable of quick action. It is also not an absolutely individual mystery. Rather, it is a condition or circumstance in which Hamlet himself is clearly irresponsible for his uncle's corruption but invited to devise ways to counteract it. Hamlet's mystery is probably not one of a thinker's bewilderment that arises as the playwright creates a surprising feeling for a hero's life; a life in which we do not find even a simple starting point for its intertwined actions. And because we cannot find clues to interpret the causes and consequences of Hamlet's melancholy we are also unable to understand or accept the complexities of this ambiguous Shakespearian hero.

One key feature of Hamlet's doubt is his so-called madness. Hamlet's madness is determined by moments of ambiguity that it is not at all easy to decide whether he is really mad or that he is just feigning madness. The problem is that although he declared his intentions (to Horatio) that he would act as a "slapstick character", there are instances in the play in which Hamlet appears like a fool person (especially in his interviews with Ophelia during the scene of the grave diggers when he confronts Laertes). And though it may be possible to determine in some parts of the play whether Hamlet's insanity is real or pretended, the question still remains - what kind of madness is it that we see in Hamlet?

Hamlet's madness - which shrinks the unique and worthy patterns of his speech into an ordinary disease (melancholy) enables him to camouflage his identity and to hide his intentions from his supposed opponents. He has direct reasons for being "black" and also clearly declares that he will intentionally act abnormally. Perhaps we still have to abide by the possibility that he was intentionally becoming insane in certain situations during the play. There is a symbolic significance in his words to Horatio (Chapter 1, Scene 5) which show that he is roleplaying and not acting as the real Prince Hamlet of Denmark we know in the play. He declares openly that he will speak in a suspicious and ambiguous manner [that carries more than one meaning]. This aspect of his insanity sounds more like deliberate than natural. Hamlet manipulates language and hides his real identity in order to deceive us into believing that he has lost his mind.

\section{Doubt: A Mirror of Human Personality}

\subsection{Doubt as an Expression of Degraded Human Personality}

Modern types of psychoanalytic criticism treat the manipulative and deceptive use of language as evidence of the disordered and degraded nature of human personality. Hamlet, like many other Shakespearean characters is fond of mystery and puns. His beguiling word play takes the form of misleading others for his own purpose. His own torrents perplex and baffle all other characters including Gertrude, Claudius, Ophelia and Rosencrantz and Guildenstern. Of all Shakespeare's personalities, Hamlet is the deceiver [Through pun] and at the same time also the miserable. He suddenly became aware of the power of words when he complained about the gravedigger's use of language against him: "We have to speak to him in the strictest terms [in a way that is not ambiguous], otherwise confusion and thumb will kill us." (Act 3, scene 1). Polonius notes Hamlet's wordplay and comments on the connection between insanity and language skills: "Sometimes fill in his answers! It's ingenuity often matches insanity." However, Ophelia's madness - which leads her to gossip over lost celibacy and escape - does not include this insidious wordplay. The master who informs Gertrude of Ophelia's insanity prominently underscores her intermittent speech. In any case, from the point of view of psychoanalytic theory, Hamlet's manipulation of words not only reduces the status of other people but - more importantly - reveals Hamlet's degraded personality.

Hamlet's debased sense of self comes from the feeling that his life is in some way a simulacrum of the real world, and that everything that shapes his opinion of others and of things may be pure error. This is perhaps what Shakespeare meant in his declaration in his last comedy through Prospero, the hero of The Tempest, which "The world is a void in a void, an endless nebulous void."(Act (5, scene 2). Shakespeare's theater can therefore be approached in the major central context of "knowledge and suspicion" typical of Cartesian philosophical skepticism which lingered over the Renaissance and 
throughout the seventeenth century. On the horizons of the philosophy of doubt, Hamlet revolves between two main propositions: The nature of the human soul," which Shakespeare often puts to a true moral test and the main plot around which the work revolves, and which also evokes questions of relevance to destiny and degraded human personality.

3.2. Doubt as a Mirror of Unconscious Drives

An important explanation of Hamlet's madness, doubt and eccentric behaviour can be found in psychoanalysis. In his book The Interpretation of Dreams Sigmund Freud argues that Hamlet's behaviour sheds light on the depth of the human psyche. Freud starts from Hamlet's procrastination and the delay in revenge to account for his odd behaviour. A comparison between Hamlet and revenge plays that were common at the time shows that what happens in the rest of these plays is that the hero cannot reach the person he has to kill, so the play goes on and the hero tries to overcome obstacles to reach his victim. However, in Hamlet, there are no physical obstacles which prevent the act of revenge. The circumstances rather seem favorable, but Hamlet does not carry out his father's will. Performative action is perhaps prevented by thwarted desires inside Hamlet's psyche. In his explanation of human behaviour, Freud emphasizes early childhood and considers it an influential stage during which feelings are supressed. Freud who interpreted Hamlet's behaviour according to the Oedipus complex argues that Hamlet hesitated to carry out his father's commandment because Claudius reminds him of himself. The latter is rather a reflection of Hamlet's suppressed desires. When Lacan is evoked in such a context, it is his notion of the unconscious repetition in The Four Fundamental Concepts of Psychoanalysis that probably erxplains Hamlet's odd behaviour regarding revenge and his taking refuge in contemplative thinking and mental aberration. For Lacan, (Hamlet's) memory of the past (in the play his memory of what happened) erupts through repetitive thinking about what he might do about what has happened (the crime of killing the prince, marrying Gertrude, Hamlet's mother, and taking the throne). Lacan's idea is perhaps that Hamlet's quest for revenge vanished for a while from his mind without his knwledge and it returns to memory through repetitive thinking about the past.

Freud also believes that the Oedipus myth represents an important stage in the psychological development of human beings. He suggests that all children go through a stage in their childhood when they wish to kill their fathers and marry their mothers. This desire is unconscious, but its effect is no less real. When Hamlet was a child he had desired his mother sexually and wished to kill his father and gain seizure of his mother's body. Hamlet possesses the same sinful desires as Claudius, explains why he was so dubious about killing Claudius and did not consider himself worthy of this action. For Freud, Hamlet, like all adult males, must have gone through the oedipal phase and effectively suppressed his oedipal feelings but a crisis occurred in his life and made his pent-up desires resurface. These desires in turn completely nullified Hamlet's ability to act. Hamlet is not aware of this harmful conflict within himself, but reveals his existence to the audience through certain symptoms in his language and behaviour. Freud rather puts it clearly in The Interpretation of Dreams:

Hamlet can do everything but take revenge on the man who removed his father and took his place with his mother, the man who, then, shows him his childish desires have been fulfilled. Thus, for him, the atrocity of the crime which was enough to drive him to revenge is replaced by self-reprimand and fear of conscience. (83)

Freud goes even further by likening Hamlet to king Oedipus who killed his father and married his mother. He uses the Oedipus complex as a background to his position showing that Hamlet like all children developed an emotional inclination to his mother. This inclination transforms into sexual desires directed towards the mother that gradually increase in intensity, and the father seems to impede the realization of these desires. It is from this stipulation that the Oedipus complex arises. The oedipal stage is not completely bypassed because abandonment of a mother's love is only done by suppressing unconscious estrangement. Pent-up desires never leave us: they remain wholly awaiting moments of crisis in an adult's life. In other words, mature adulthood has a price. If the Oedipus complex is not successfully overcome, the son will still retain a satisfactory love and will find it difficult to transfer to natural love [between the two sexes].

Following Freud, Ernest Jones also explains Hamlet's hesitation in psychological terms. Hamlet identifies himself with Claudius because he did the same thing that the son unconsciously wanted to do. His guilty feelings (voiced by the ghost) push him to avenge Claudius, but he stops because in killing Claudius he will kill himself ${ }^{3}$. The reflections of Freud and Jones highlight dramatic psychological changes in Hamlet's personality. The main feature of Hamlet's behavior that demands explanation is his so-called madness. The problem is that although he declared his intentions (to Horatio) that he would take a "slapstick character," there are instances in the play in which Hamlet acts like a fool person (especially in his interviews with Ophelia during the scene of the gravediggers when he confronts Laertes). As a result, it may not be possible to determine whether Hamlet's insanity is real or presumed. In other parts of the play, however, the question still remains: what kind of madness is it that characterizes Hamlet?

Taking into account Hamlet's madness - which shrinks the unique and worthy patterns of his speech into an ordinary disease (melancholy) - one realizes that there are instances in the play when Hamlet loses the ability to persuade the audience that he is mad. One cannot treat Hamlet's apparent behavior as in one sense his innate character. He has direct reasons for presuming madness and also clearly declares that he will intentionally act abnormally when he openly tells Horatio (Act 1 , Scene 5) that he will speak in a suspicious and ambiguous manner. Inspite of this, one still has to keep the possibility that he was really just getting insane in certain situations during the play. This change in the hero's behaviour provides a clear indication of his degraded personality. Polonus notes Hamlet's wordplay and comments on the connection between insanity and language skills: "Sometimes fill in his answers! It's ingenuity often matches insanity." However, Ophelia's madness which leads her to gossip over lost celibacy and escape - does not include this insidious wordplay. The master who informs Gertrude of Ophelia's insanity underscores prominently her interrupted speech which is also a sign of her perturbed psyche. 


\section{Conclusion}

In Hamlet, the phenomenon of doubt associated with Shakespeare's hero raises a complex philosophical question about whether it possible for the individual to establish certain knowledge about anything in the world. The philosophical anxiety of prince Hamlet throughout his revenge journey not only reflects the degraded nature of human personality in Shakespeare's era but also recalls minding the writings of Plato and the sayings of Socrates before him. To some extent Hamlet functions as a review of ancient Socratic skepticism and an introduction to modern epistemological certainty. The principle of doubt in all human knowledge is Shakespeare's central philosophy in Hamlet.

Throuhout the play prince Hamlet seems totally unsettled and dubious about even trifle actions. He oscillates between decision and indecision, action and inaction, and is severely at odds with the world surrounding him. He is unable to distinguish reality from unreality and spends too much time thinking about what may ensue should he act in one way or another. His life seems in some way a simulacrum of the real world, and everything that shapes his opinion of others and of things may be pure error. This is perhaps what Shakespeare meant when he openly pronounced in his last play through Prospero's tongue that "The world is a void in a void, an endless nebulous void."(Act (5, scene 2). Shakespeare's focus on the state of epistemic uncertainty and confusion between the real and unreal is similar to Socrates's early philosophical discussions on skepticism, which lends the play its philosophical dimension.

Hamlet's world is interrogative. The play is full of questions, alerts to danger, pains, and reflections. And the world of Hamlet is the world of mysteries. The hero's own language is an enigmatic language. When he plays with words, he reaches their depths. His manner of speaking displays a state of insanity. And the mystery of Hamlet's world is an important question starting "from its first word in its first mysterious scene in the middle of that cold night at Elsinore. Hamlet's life is so mysterious and unpredictable. None can predict the outcome of his actions, and it is perhaps for this reason that Shakespeare created the problem of being slow to take revenge. We do not feel throughout the play that Hamlet has abandoned the act of revenge and we do not similarly notice his willigness to act it out.

\section{References}

Cott, J. (1964). Shakespeare Our Contemporary. Garden City, NewYork, Doubleday.

Coleridge, S. T. (1961). Shakespearen Criticism. London: J. M. Dent \& Sons.

Elliott, G. R. (1951). A Study of Hamlet as a Tragedy of Revengefulness and Justice. Durham, N. C: Duke University press: London: Cambridge University press.

Freud, S. (1899). The Interpretation of Dreams. Franz Deuticke, Leipzig \&Vienna.

(1905) Three essays on the theory of Sexuality. German: Drei Abhandlungen zur Sexualtheorie.

Heywood, Thomas (1978). Apology for Actors. I.G, New York: Scholars Facsimiles and reprints.

Jones, E. (1949). Hamlet and Oedipus. London: V. Gollancz.

Lacan, Jacques (1979) The Four Fundamental Concepts of Psychoanalysis, trans. Alan Sheridan, Harmondsworth: Penguin.

Ornstein R. (1960). The Moral Vision of Jacobean Tragedy. University of Wisconsin: University of Wisconsin press. Shakespeare, W. (1623). Hamlet. The First Folio.

- (1623) .The Tempest. The First Folio.

Stagiritis, A. (1961). The Poetics. New York: Hill and Wang.

\section{Endnotes}

\footnotetext{
${ }^{1}$. Of all Shakeseare's plays Jan Kott wrote of Hamlet in particular: "Hamlet' is like a sponge. Unless it is produced in a stylised or antiquarian fashion, it immediately absorbs all the problems of our time." His chapter on Hamlet focused on a Polish performance just after the end of Stalinism (Stalin hated this play, of course). Kott wrote, "here on the public stage was what Hamlet meant in 1956, there and then: 'It was a political drama. Everybody, without exception, was being consistently watched... unequivocally and with a terrifying clarity.'

2. The expression "Weird mood" was used by Adrian Bardon, a professor of philosophy at Wake Forest University in his book entitled A Brief History of the Philosophy of Time.

3. Freud and Jones explain Hamlet's hesitation to kill his uncle Cladius in psychological terms. Claudius's crime also echoes Hamlet's suppressed desire to kill his father and marry his mother.
} 